\title{
Biorational and conventional insecticides efficacy to control thrips (Frankliniella occidentalis Perg.) on strawberries (Fragaria $\times$ ananassa Duch.) at Morelos state, Mexico
}

\author{
Monteon-Ojeda Abraham ${ }^{1}$; Damián-Nava Agustín ${ }^{1}$; Hernández-Castro Elías ${ }^{1 *}$; \\ Cruz-Lagunas Blas $^{1}$; Romero-Rosales Teolincacihuatl ${ }^{1}$; San Juan-Lara Jorge ${ }^{2}$; \\ Ibarra-Cortes Karla $\mathrm{H}^{3}$ \\ 1 Universidad Autónoma de Guerrero, Iguala, Guerrero, México. C.P. 40040. \\ 2 Universidad Politécnica de Francisco I. Madero, Tepatepec, Hidalgo, G.P. 42660. \\ 3 Universidad Tecnológica de Bahía de Banderas, Nuevo Vallarta, Nayarit. C.P. 63732. \\ * Correspondence: ehernandez@uagro.mx
}

Gitation: Monteon-Ojeda, A. Damián-Nava, A., Hernández-Castro, E., Cruz-Lagunas, B., Romero-Rosales, T., San Juan-Lara J., \& IbarraCortes, K. H. (2021), Biorational and conventional insecticides efficacy to control thrips (Frankliniella occidentalis Perg.) on strawberries (Fragaria $\times$ ananassa Duch.) at Morelos state, Mexico. Agro Productividad. https://doi.org/10.32854/agrop. v14i9.1980

Editor in Chief: Dr. Jorge Cadena Iñiguez

Received: March 15, 2021. Accepted: August 9, 2021.

Published on-line: October 12, 2021

This work is licensed under a Creative Commons Attribution-NonCommercial 4.0 International license

\section{(1) ()}

\section{ABSTRACT}

Objective: To evaluate the insecticidal effectiveness of biorational and conventional products as alternatives to control thrips and their phytotoxic effects in strawberry cultivation.

Design/methodology/approach: The research was carried out in strawberry cv. Camino Real during its flowering stage - fruiting established in open ground; A completely randomized experimental design with seven treatments and four replications was used. The treatments evaluated were: T1: neem oil extract, T2: paraffin oil, T3: garlic extract + hot chili pepper + cinnamon, T4: spinosad, T5: imidacloprid + lambda cyhalothrin, T6: bifenthrin, and T7: control. Applications were made weekly and the mortality evaluation was carried out by counting the number of live thrips per flower. With the obtained data, an analysis of variances and a mean comparison test (Tukey, $\mathrm{p} \leq 0.05$ ) were performed.

Results: Significant differences between treatments could be identified ( $\mathrm{s} \leq 0.05)$; imidacloprid + lambda cyhalothrin and bifenthrin caused the highest mortality of thrips with 92 and $93 \%$ efficacy, respectively. Spinosad obtained good results, ranking as the second-best option with 90\% control efficiencies; neem extract stood out as an excellent biorational pest management alternative with $77 \%$ control efficacy in its last evaluation. No phytotoxic effects were observed from any of the treatments on the crop.

Limitations on study/implications: It is important to continue the study in the laboratory to obtain the LD50 and LD90 of the management alternatives, as well as an MRL analysis of the molecules used.

Findings/conclusions: The proposed protocol evidenced the efficacy of biorational and ecological thrips control treatments in intensive horticultural systems.

Keywords: ecological management, extract, identification, neem, spinosad. 


\section{INTRODUGTION}

In Mexico, the strawberry (Fragaria $\times$ ananassa) cultivation began around the middle of the last century and in 1950 began to be exported to the United States. In the country, strawberries are one of the most important productive chains, due to the production value estimated at more than 100 million dollars every year (SIAP, 2019), as well as being an important source of employment in their production regions. Its planted area is more than 7 thousand hectares, although in Mexico the crop occupies only $1 \%$ of the area dedicated to agriculture. It is important for the generation of foreign exchange because it is an export product. In Mexico, the states of Michoacán, Baja California and Guanajuato generate more than $90 \%$ of total production.

The strawberry crop presents multiple phytosanitary constraints among which pests such as red spider mite (Tetranychus urticae), western tarnished plant bug (Lygus hesperus), western flower thrips (Frankliniella occidentalis), corn earworm (Helicoverpa zea), and white grubs (Phyllophaga ssp.) stand out (León-López et al., 2014); the main diseases in this crop are caused by Botrytis spp., Colletotrichum spp., and Phytophthora spp. (fruit rot); Fusarium moniliforme, Rhizoctonia solani, Verticillium dahliae and Alternaria spp. (strawberry blotch); Fusarium oxysporum (root and crown rot); strawberry mottle $(\mathrm{SMoV})$ and strawberry sprouting (SCV) (Dávalos et al., 2011; Cordero et al., 2003; León López et al., 2014; TélizOrtíz et al., 1986). The "western flower thrips or Californian thrips" (F. occidentalis) is native to the southwestern United States and have a worldwide distribution. Its polyphagy, combined with its high biotic potential, allows it to generate large populations of individuals that infest the crops. The adults and larvae of F. occidentalis scrape and suck the fluid from the cells on the surface of stems, leaves, flowers and fruits; in flowers they cause veining, discoloration (silver-gray spots) and petal necrosis, which reduces yield and product quality (Albendin et al., 2012). In fruits, high populations (25 thrips/fruit) cause spots, scarring, tanning, deformations and softening that reduce commercial quality (especially for export) and shorten shelf life (Albendin et al., 2012; Coll et al., 2007). Additionally, the flower thrips is one of the most efficient species for the transmission of the tomato spotted wilt virus (TSWV) (Parrella et al., 2003). In Mexico and many areas of the world, thrips control is conventionally based on using synthetic translaminar contact and broad-spectrum chemical insecticides such as chloronicotinyls (imidacloprid), ketoenols (spiromesifen, spirotetramat), phenylpyrazoles (fipronil) and pyrethroids such as cypermethrin, deltamethrin and abamectin (Monteon-Ojeda et al., 2020). It is important to mention that, although effective, these types of products have other disadvantages such as the possible selection of resistance, environmental pollution, human intoxication during its application, in addition to placing food safety at risk (Monteon-Ojeda et al., 2020). On this basis, the objective of this research was to evaluate the insecticidal effectiveness of biorational and conventional products as alternatives for the control of flower thrips in strawberries, as well as their possible phytotoxic effects on the crop.

\section{MATERIALS AND METHODS}

The study was carried out during June and July 2020 at the "ejido" Cacahuatlán, Tlayacapan, Morelos; $18^{\circ} 55^{\prime} 22^{\prime \prime} \mathrm{N}$ and $99^{\circ} 00^{\prime} 22^{\prime \prime} \mathrm{W}$. The temperature and relative 
humidity variables were recorded throughout the experiment using an electronic temperature and relative humidity meter, $\mathrm{HOBO}^{\circledR}$ model $\mathrm{U} 12$, and ranged between $23 \pm 2{ }^{\circ} \mathrm{C}$ and $65 \pm 10 \%$ respectively. The research took place in a commercial strawberry plantation (Fragaria $\times$ ananassa) cv. Camino Real during its flowering - fruiting stage and established in open ground. The plants were established in a double row furrow in an offset "tresbolillo" arrangement, at a $40 \mathrm{~cm}$ distance between plants and 1.25 meters between rows. In the furrow, gray embossed padding was used. For the irrigation system, drip tape was used, 8000 gauge with a dropper every $40 \mathrm{~cm}$ and a flow rate of $1.5 \mathrm{~L} \mathrm{~h}^{-1}$. For nutrition, a Steiner nutrient solution adjusted to a $\mathrm{pH}$ of 5.5 was daily applied.

The treatment application was done in the mornings, from 7:30-8:30 am in cool conditions $\left(15-18{ }^{\circ} \mathrm{C}\right)$ and low wind speed $(0-3 \mathrm{~km} / \mathrm{h})$. Three applications were made for treatments T1, T2, T3 and T7 (control) and two for T4, T5 and T6 with a seven days interval between them. The spraying of insecticides was foliar, using a motorized gasoline sprayer backpack of $25 \mathrm{cc} \mathrm{Honda}^{\circledR}$ with a full cone nozzle at a constant pressure of 250$300 \mathrm{psi}$, calibrated at a flow rate of $400 \mathrm{~L} / \mathrm{ha}$. Treatments of both natural and synthetic origin were used, following: T1: neem oil extract (Azadirachtin indica) (80\%) at a dose of 1.4 L/ha, T2: paraffinic oil (95\%) at a dose of 2.0 L/ha, T3: garlic extract (Allium sativum) 25\% + hot chili extract (Capsicum frutescens) 25\% + cinnamon extract (Cinnamomum zeylanicum) $10 \%$ at a dose of $2.0 \mathrm{~L} / \mathrm{ha}$, T4: spinosad $12 \%$ at $60 \mathrm{mg} \mathrm{\textrm {L } ^ { - 1 }}$ dose, T5: imidacloprid + lambda cyhalothrin $(200+140 \mathrm{~g} / \mathrm{L} \mathrm{SG})$ at $200 \mathrm{~mL} /$ ha dose, T6: bifenthrin (110 g/L EG) at $400 \mathrm{~mL} /$ ha dose and T7: control without insecticide application (water). The doses and active ingredients used were selected based on technical recommendations and previous studies.

For the experiment evaluation, systematic samplings (following a type $\mathrm{Z}$ pattern) of the thrips populations were carried out before and after the application of the insecticides. A previous evaluation and three subsequent ones were performed at 7, 14 and 21 days after the first spraying (dafs). From each experimental unit (EU), 10 plants were reviewed and from each plant two flowers (20 flowers per EU), the number of live thrips per flower was assessed. Also, samples of the found specimens were taken with a manual sprinkler and a water and fabric softener solution (9:1), the thrips were recovered in a plastic tray and with a sieve deposited in glass flasks with $70 \%$ methanol for laboratory identification. The identification was carried out with illustrated keys for the Thysanoptera genera and species of Frankliniella (Cavalleri and Mound, 2012; Moritz et al., 2001; Soto and Retana, 2003) and corroborated by expert entomologist M.C. Jorge San Juan Lara. In addition to the aforementioned, an evaluation of the possible phytotoxic effect of the products applied on the crop was carried out three days after each application, EWRS damage scale was used (Champion, 2000). The efficacy of the treatments was evaluated using a completely randomized experimental design with four replications. Before the treatment application, the experimental units were randomized using the "design.ab" procedure in the $\mathrm{R}$ statistical software for Windows. This randomization determined which treatment was assigned to each EU. The efficacy percentage (\%) of thrips control was calculated by counting the live individuals per flower in each EU after the application of the treatments, following the Abbott formula: 


$$
\% \text { Effectiveness }=\frac{I T-i t}{I T} \times 100
$$

Where: $I T=$ absolute control infestation, $i t=$ treatment infestation.

A normality analysis of the distribution of the errors was performed on the obtained variable using the Shapiro-Wilk test, homogeneity of variances with the Bartlett test and graphically using residuals $v s$. predicted to verify assumptions. With the efficacy data obtained in the evaluations, an analysis of variance and a comparison test of means were performed with the Tukey method $(\alpha=0.05)$ using the SAS V.9.4 statistical software for Windows ${ }^{\circledR}$.

\section{RESULTS AND DISCUSSION}

The present thrips specimens were counted, registering the presence of immature and adult forms. Most of the collected specimens were identified as Frankliniella occidentalis (Pergande) (Thysanoptera: Thripidae). This species has been reported as a common and high impact pest in this crop (González-Zamora and García-Marí, 2003; Matos and Obrycki, 2004; Solano-Rojas et al., 2018). The occurrence of immatures was occasional, the adults had the highest abundance. In multiple species of thrips, adults can be found in hundreds of plants, while larvae are hardly captured (Carrizo, 2002). The analysis of the thrips records during the evaluations showed that, at the beginning (previous evaluation), the population in the experimental units was homogeneous and had a normal behavior, so the corresponding statistical assumptions were met; the average number of thrips per inflorescence was of 9.5 individuals, an infestation high enough to cause substantial crop losses (Figure 1).

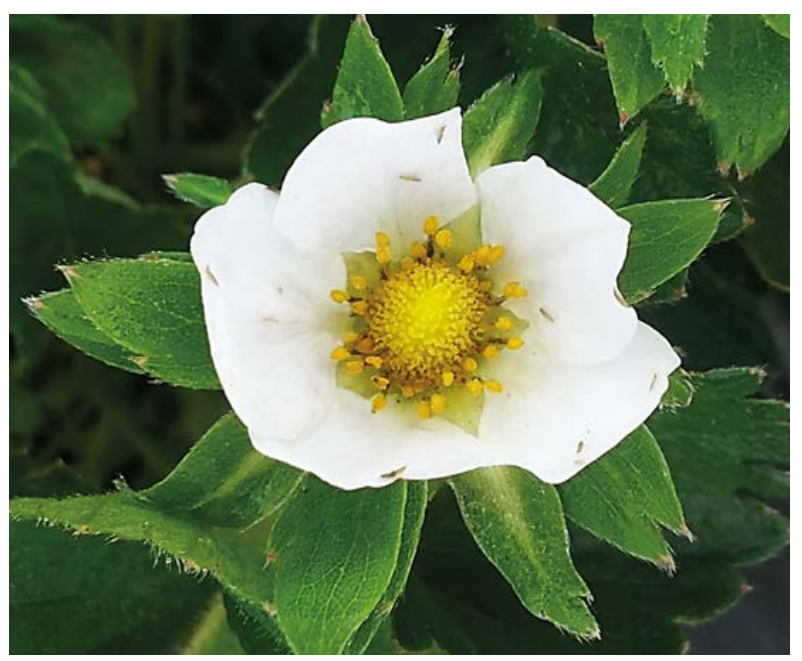

Figure 1. Infestation of thrips (Frankliniella occidentalis) in strawberry flowers (Fragaria $\times$ ananassa) cv. Camino Real previous evaluation of biorational and conventional control treatments at Tlayacapan, Morelos, 2020. 
The analysis of variance and means comparison of the recorded field data identify significant differences in the populations of thrips during the first evaluation of insecticide treatments, carried out seven days after the first application; all insecticide treatments had a significant effect $(\mathrm{p} \leq 0.05)$ on the thrips population (Table 1). imidacloprid + lambda cyhalothrin and bifenthrin caused the highest mortality of thrips, spinosad also obtained good results, ranking as the second-best option; the neem extract showed a decrease of more than half of the population in its experimental units. Also, paraffinic oil and combined plant extract (T3) obtained the lowest mortality levels, although significant (Table 1). The treatment's behavior during the second and third evaluations was similar, highly significant differences $(\mathrm{p} \leq 0.05)$ were observed between them. Spinosad proved to be an exceptional control option, by causing mortality similar to that of conventional synthetic insecticide treatments (T6 and T7), which maintained the lowest populations throughout the experiment; although the other biorational treatments (T1, T2 and T3) did not reach the same mortality levels, they proved to be an excellent option, by reducing with just three applications, more than $60 \%$ the population affecting the strawberry flowers. Neem oil extract is highlighted as an excellent pest management alternative (Table 2). These results concur with that reported by Kharbade et al. (2018) who is a field experiment evaluated insecticidal treatments to reduce the infestation of thrips (Thrips tabaci L.) in onion crops. Their results revealed that the treatment with fipronil 5 SC was the most promising when registering the accumulated mean population lowest thrips of 4.38 thrips/plant and was on a par with clothianidin 50 WDG (4.69 trips/plant), the next best treatments in order of efficacy were carbosulfan + bifenthrin, lambda-cyhalothrin 5 EC, bifenthrin $10 \mathrm{EC}$, carbosulfan $25 \mathrm{EC}$ which registered 6.44, 6.69, 6.91 and 7.15 trips/plant, respectively; followed by spinosad $45 \mathrm{SC}$, thiamethoxam $25 \mathrm{WG}$, rynaxypyr 18.5 SC and Metarhizium anisopliae in which $8.04,8.22,8.42$, and 8.75 trips/plant were observed, respectively. The untreated control registered the highest population (23.70 trips/plant). Also coinciding with what was reported by Nderitu et al. (2010), who in a field experiment to evaluate and compare the effectiveness of synthetic insecticides (thiacloprid and chloropyrifos) and botanical insecticides (azadirachtin $0.15 \%$ and azadirachtin $0.06 \%$ ) to control Frankliniella occidentalis populations and Megalurothrips sjostedti in beans (Phaseolus vulgaris L.) found significant differences $(\mathrm{p}<0.05)$ between the four treatments, the lowest number of adult thrips and larvae were recorded in plots treated with $0.15 \%$ azadirachtin and Chlorpyrifos. In terms of yield, the plots treated with Chlorpyrifos, produced more marketable pods than those treated with botanical insecticides in both plantations, for which they recommended the use of chlorpyrifos at the beginning of the season to reduce thrips populations and applying $0.15 \%$ azadirachtin during the fruiting stage, to reduce the cost of production and allow the increase of natural enemies reducing the risk of resistance development. In Australia, Kay and Herron (2010) found that spinosad had the greatest impact on adults; in other studies, the effectiveness of spinosad to control immature and mature stages of F. occidentalis in cucumber greenhouses has been reported (Gholam and Sadeghi, 2016; Jones et al., 2005). Alike to is reported in this bioassay, Thoeming et al. (2003) evaluated the systemic effects of neem (azadirachtin) applied to soil for the control of flower thrips (F. occidentalis) in beans (P. vulgaris) grown in multiple substrates. The applications of 
Table 1. Results of the survival analysis of thrips (Frankliniella occidentalis) in strawberries (fragaria $\times$ ananassa) cv. Camino Real under biorational and conventional control treatments during the previous evaluation and first evaluation, at Tlayacapan, Morelos, Mexico (2020).

\begin{tabular}{|c|c|c|}
\hline Treatments & $\begin{array}{l}\text { Pre- evaluation } \\
(0 \text { dafs } *)\end{array}$ & $\begin{array}{l}\text { First evaluation } \\
\text { (7 dafs) }\end{array}$ \\
\hline T1: Oil neem spray & $9.40 \mathrm{a}^{* *}$ & $3.24 \mathrm{c}$ \\
\hline T2: Paraffinic oil & $9.30 \mathrm{a}$ & $5.26 \mathrm{~b}$ \\
\hline T3: Garlic extract + hot chili extract + cinnamon extract & $9.50 \mathrm{a}$ & $5.28 \mathrm{~b}$ \\
\hline T4: Spinosad & $9.55 \mathrm{a}$ & $2.37 \mathrm{~d}$ \\
\hline T5: Imidacloprid + lambda cyhalothrin & $9.35 \mathrm{a}$ & $1.71 \mathrm{e}$ \\
\hline T6: Bifenthrin & $9.40 \mathrm{a}$ & $1.75 \mathrm{e}$ \\
\hline T7: Control & $9.12 \mathrm{a}$ & $9.67 \mathrm{a}$ \\
\hline
\end{tabular}

* Days after the first spraying.

** Means with different letters in the same column statistically differ according to the Tukey Test $(\mathrm{p}<0.05)$.

Table 2. Results of the survival analysis of thrips (Frankliniella occidentalis) in strawberries (Fragaria $\times$ ananassa) cv. Camino Real under biorational and conventional insecticide treatments for control during a second and third evaluation, Tlayacapan, Morelos, Mexico (2020).

\begin{tabular}{l|c|c}
\multicolumn{1}{c|}{ Tratamientos } & $\begin{array}{c}\text { Segunda } \\
\text { evaluación } \\
\left(\mathbf{1 4} \mathbf{~ d a f *} \mathbf{*}^{*}\right.\end{array}$ & $\begin{array}{c}\text { Tercera evaluación } \\
\text { (21 dafs) }\end{array}$ \\
\hline T1: Oil neem spray & $2.97 \mathrm{c}$ & $2.15 \mathrm{c}$ \\
\hline T2: Paraffinic oil & $3.72 \mathrm{bc}$ & $3.23 \mathrm{~b}$ \\
\hline T3: Garlic extract + hot chili extract + cinnamon extract & $4.51 \mathrm{~b}$ & $3.62 \mathrm{~b}$ \\
\hline T4: Spinosad & $1.09 \mathrm{~d}$ & $0.91 \mathrm{~d}$ \\
\hline T5: Imidacloprid + lambda cyhalothrin & $0.74 \mathrm{~d}$ & $0.77 \mathrm{~d}$ \\
\hline T6: Bifenthrin & $0.72 \mathrm{~d}$ & $0.65 \mathrm{~d}$ \\
\hline T7: Control & $9.75 \mathrm{a}$ & $9.17 \mathrm{a}$ \\
\hline
\end{tabular}

* Days after the first spraying.

** Means with different letters in the same column statistically differ according to the Tukey Test $(\mathrm{p}<0.05)$.

azadirachtin in the sand substrate recorded maximum mortality of $50.6 \%$ against immature when the substrate based on microcosm was used, $76 \%$ mortality was observed and in the mixture of substrates in a 1:1 ratio, 93\% mortality was observed, the effects against thrips were kept up to 6 days after application. It should be taken into that the number of thrips in the crop after the application of neem-based products should not be a sole measure of the effectiveness of the product. This is because azadirachtin has a wide range of effects on pest insects, such as deterring feeding and oviposition, repellent effects, regulation of insect growth, sterilant, mating disruptor and toxicity (Nderitu et al., 2010; Singh and Doharey, 2001).

The analysis of the efficacy percentages was able to identify a continuous increase and a similar behavior during the three evaluations carried out in all insecticide treatments (Figure 2). Although, for the biorational treatments (T1, T2 and T3), three consecutive weekly applications were necessary to reach acceptable levels of infestation control. These are justified considering its chemical origin, residuality and low cost. The neem oil extract 


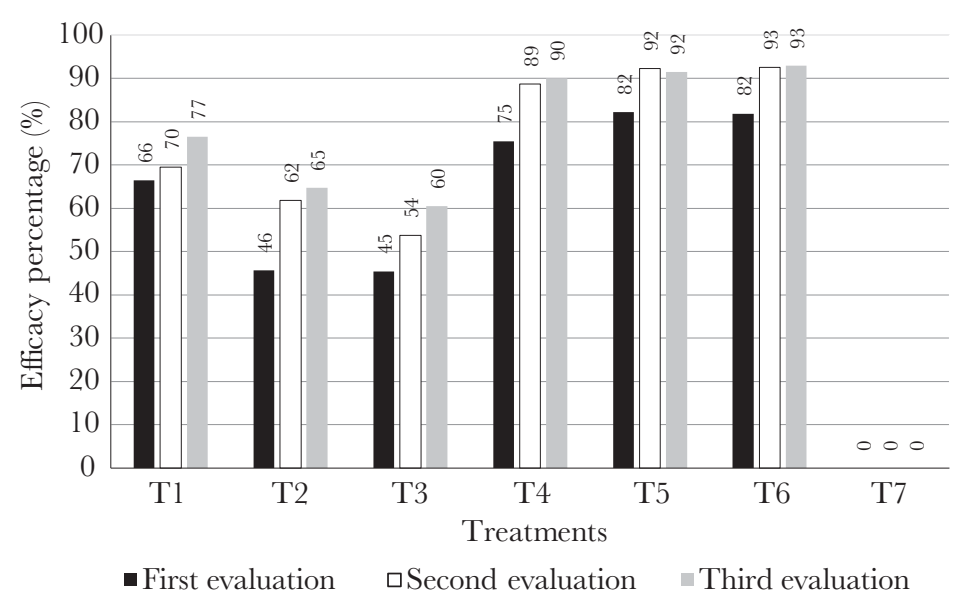

Figure 2. Control efficacy of biorational and conventional insecticides for the management of thrips (Frankliniella occidentalis) in strawberries (Fragaria $\times$ ananassa) cv. Camino Real, at Tlayacapan, Morelos, Mexico (2020). * T1: Neem (Azadirachtin indica) oil extract (80\%) at a $1.4 \mathrm{~L} /$ ha dose, T2: paraffin oil (95\%) at a $2.0 \mathrm{~L} /$ ha dose, T3: garlic (Allium sativum) 25\% extract + hot chili (Capsicum frutescens) 25\% extract + cinnamon (Cinnamomum zeylanicum) 10\% extract at a dose of $2.0 \mathrm{~L} / \mathrm{ha}$, T4: Spinosad $12 \%$ at a60 $\mathrm{mg} \mathrm{L}^{-1}$ dose, T5: imidacloprid + lambda cyhalothrin $(200+140 \mathrm{~g} / \mathrm{L} \mathrm{SC})$ at a $200 \mathrm{~mL} / \mathrm{ha}$ dose, T6: bifenthrin $(110 \mathrm{~g} / \mathrm{L} \mathrm{EG})$ at a $400 \mathrm{~mL} /$ ha dose and T7: control without insecticide application (water).

stands out because it reached $77 \%$ effectiveness during the third evaluation; spinosad was the best treatment with ecological characteristics, reaching $90 \%$ efficacy with only two applications, positioning it as the best non-synthetic option for the control of thrips in strawberries (Figure 2). The foregoing suggests that two or three consecutive applications every seven days of these biorational insecticides are sufficient to maintain the thrips populations at acceptable levels. The alternation of treatments is recommended, starting, for example, with an application of spinosad or bifenthrin, followed by two applications of neem extract, rotating the molecules in later production cycles. Coinciding with our results, Thoeming and Poehling (2006) evaluated using Neem-Azal-U (17\% azadirachtin), a formulation developed for the absorption of roots against $F$. occidentalis in beans. There, the treatment caused mortalities from 70 to $98 \%$ after soil application, they also reported that a combination of azadirachtin with predatory mites resulted in efficiencies of up to 99\%. Similarly, Kay and Herron (2010) evaluated insecticidal treatments for the control of $F$. occidentalis in peppers (Capsicum frutescens) and reported that spinosad achieved 98 to $100 \%$ control efficacy. It is important to mention that, throughout the trial, no treatment produced phytotoxic effects on the crop, the above contributes and justifies the use of biorational products.

\section{CONGLUSIONS}

All insecticide treatments had a negative effect on the populations of $F$. occidentalis in strawberries; the highest efficacy percentages were recorded during the third evaluation, which occurred 21 days after the first application. These were obtained by spinosad, imidacloprid + lambda cyhalothrin and bifenthrin. However, three consecutive applications of neem extract are sufficient to reduce infestation of the pest by more than 
$75 \%$ in strawberries. This research shows that the incorporation of biorational products in the thrips management could reduce the high usage of synthetic pesticides and delay the development of resistance, as well as an ecological strategy to reduce the effect on natural enemies. Therefore, its incorporation into an integrated pest management system is recommended for this crop.

\section{REFERENGES}

Albendin, G., García, M. C., Molina, J. M. (2012). El trips de las flores y su control en el cultivo de la fresa. Disponible en: http://www.eumedia. es/portales/files/documentos/dossier_trips_VR348. pdf.

Carrizo, P. (2002). Establishing a weed host ranking for thrips vectors of tospovirus in La Plata horticultural belt of Buenos Aires, Argentina. In Thrips and tospoviruses: Proceedings of the 7th International Symposium on Thysanoptera. Section VII: Control Strategies (pp. 239-248).

Cavalleri, A., Mound, L. A. (2012). Toward the identification of Frankliniella species in Brazil (Thysanoptera, Thripidae). Zootaxa, 3270(1), 1-30. Doi: 10.11646/zootaxa.3270.1.1

Champion, G. T. (2000). Bright and the field scale evaluations herbicides tolerant. G M Trials. AICC Newslwtter, 7.

Coll, M., Shakya, S., Shouster, I., Nenner, Y., Steinberg, S. (2007). Decision making tools for Frankliniella occidentalis management in strawberry: consideration of target markets. Entomologia Experimentalis et Applicata, 122(1), 59-67. Doi: 10.1111/j.1570-7458.2006.00488.x

Cordero, M. D. L. F., Morales, M. D. J. Y., Angel, D. N., Gálvez, G. V. (2003). Hongos patógenos en fruto de fresa (Fragaria $\times$ ananassa Duch.) en postcosecha. Revista Mexicana de Fitopatología, 21(3), 285-291.

Dávalos, P. A., Aguilar, G. R., Jofre, A. E., Hernández, A. R., Vázquez, M. N. (2011). Tecnología para sembrar viveros de fresa. Ríos, S. A. (Ed.). Instituto Nacional de Investigaciones Forestales, Agrícolas y Pecuarias (INIFAP). la (Ed.). Celaya, Guanajuato, México, D. F. 153 pp.

Gholam, Z., Sadeghi, A. (2016). Management strategies for western flower thrips in vegetable greenhouses in Iran: a review. Plant Protection Science, 52(2), 87-98. Doi: 10.17221/2/2015-PPS

González Zamora, J. E., Garcia Marí, F. (2003). The efficiency of several sampling methods for Frankliniella occidentalis (Thysan., Thripidae) in strawberry flowers. Journal of Applied Entomology, 127(9 10), 516521. Doi: 10.1046/j.0931-2048.2003.00783.x

Jones, T., Scott Dupree, C., Harris, R., Shipp, L., Harris, B. (2005). The efficacy of spinosad against the western flower thrips, Frankliniella occidentalis, and its impact on associated biological control agents on greenhouse cucumbers in southern Ontario. Pest Management Science: formerly Pesticide Science, 61(2), 179-185. Doi: 10.1002/ps.939

Kay, I. R., Herron, G. A. (2010). Evaluation of existing and new insecticides including spirotetramat and pyridalyl to control Frankliniella occidentalis (Pergande)(Thysanoptera: Thripidae) on peppers in Queensland. Australian Journal of Entomology, 49(2), 175-181. Doi: 10.1111/j.1440-6055.2010.00751.x

León López, L., Guzmán-Ortíz, D. L. A., García Berumen, J. A., Chávez Marmolejo, C. G., Peña-Cabriales, J. J. (2014). Consideraciones para mejorar la competitividad de la región" El Bajío" en la producción nacional de fresa. Revista mexicana de ciencias agricolas, 5(4), 673-686. Doi: 0.29312/remexca.v5i4.929

Matos, B., Obrycki, J. J. (2004). Influence of thrips on bronzing of strawberry fruit. HortScience, 39(6), 1343 1345. Doi: 10.21273/HORTSCI.39.6.1343

Monteon-Ojeda, A., Damián-Nava, A., Cruz Lagunas, B., Duran-Trujillo, Y., Piedragil-Ocampo, B., Grifaldo-Alcántara, P. F., Hernández-Castro, E., García-Escamilla, P. (2020). Efficacy of botanical and biorational insecticides for thrips control (Thysanoptera: Thripidae) in mango trees in Veracruz, Mexico Eficacia de insecticidas botánicos y biorracionales para el control de trips (Thysanoptera: Thripidae) en árboles de mango en Veracruz, México. Revista Bio Ciencias, 7, e1031.

Moritz, G. B., O’Donnell, G.,Parrella, M. P. (2007). Pest thrips of North America associated with domestic and imported crops. Queensland, CD-ROM CBIT Publishing.

Nderitu, J., Mwangi, F., Nyamasyo, G., Kasina, M. (2010). Utilization of synthetic and botanical insecticides to manage thrips (Thysan.: Thrip.) on snap beans (Fabaceae) in Kenya.

Parrella, G., Gognalons, P., Gebre-Selassie, K., Vovlas, G., Marchoux, G. (2003). An update of the host range of Tomato spotted wilt virus. Journal of Plant Pathology, 85(4). 227-264.

Servicio de Información Agroalimentaria y Pesquera (SIAP). (2020). Atlas Agroalimentario 2016. Accedido en enero de 2019.

Singh R. P., Doharey, K.L. (2001). Integrated pest management in vegetables. In: Training manual-2, Training on IPM for Zonal Agricultural Research Stations, May 21-26, pp105-118. 
Solano-Rojas, Y., Giménez, A., Pérez de Camacaro, M., Morales-Sánchez, J., Zurita, G. (2018). Nuevos registros de Frankliniella occidentalis (Pergande)(Thysanoptera: Thripidae) y de Tetranychus urticae Koch (Acari: Tetranychidae) en fresas cultivadas en Venezuela. Revista Colombiana de Ciencias Hortícolas, 12(1), 69-74. Doi: 10.17584/rcch.2018v12i1.6749

Soto, G. A., Retana, A. P. (2003). Clave ilustrada para los géneros de Thysanoptera y especies de Frankliniella presentes en cuatro zonas hortícolas en Alajuela, Costa Rica. Agronomía Costarricense, 27(2), 55-68.

Téliz-Ortíz, D.; Mendoza, H. A., Sandoval J. (1986). Enfermedades de la fresa en México. Rev. Mex. Fitopatol. 1(4):1-12.

Thoeming, G., \& Poehling, H. M. (2006). Integrating soil-applied azadirachtin with Amblyseius cucumeris (Acari: Phytoseiidae) and Hypoaspis aculeifer (Acari: Laelapidae) for the management of Frankliniella occidentalis (Thysanoptera: Thripidae). Environmental entomology, 35(3), 746-756. Doi: 10.1603/0046225X-35.3.746

Thoeming, G., Borgemeister, C., Sétamou, M., Poehling, H. M. (2003). Systemic effects of neem on western flower thrips, Frankliniella occidentalis (Thysanoptera: Thripidae). Journal of Economic Entomology, 96(3), 817-825. Doi: 10.1093/jee/96.3.817. 